\title{
Lactobacillus plantarum LG42 Isolated from Gajami Sik-Hae Inhibits Adipogenesis in 3T3-L1 Adipocyte
}

\author{
Jeong-Eun Park, ${ }^{1,2}$ Suk-Heung $\mathrm{Oh},{ }^{3}$ and Youn-Soo $\mathrm{Cha}^{1,2}$ \\ ${ }^{1}$ Department of Food Science and Human Nutrition, Chonbuk National University, Jeonju 561-756, Republic of Korea \\ ${ }^{2}$ Jeonju Makgeolli Research Center, Chonbuk National University, Jeonju 561-756, Republic of Korea \\ ${ }^{3}$ Department of Food and Biotechnology, Woosuk University, Jeonbuk 565-701, Republic of Korea
}

Correspondence should be addressed to Youn-Soo Cha; cha8@jbnu.ac.kr

Received 3 October 2012; Accepted 17 December 2012

Academic Editor: Fabio Ferreira Perazzo

Copyright (C) 2013 Jeong-Eun Park et al. This is an open access article distributed under the Creative Commons Attribution License, which permits unrestricted use, distribution, and reproduction in any medium, provided the original work is properly cited.

\begin{abstract}
We investigated whether lactic acid bacteria isolated from gajami sik-hae (GLAB) are capable of reducing the intracellular lipid accumulation by downregulating the expression of adipogenesis-related genes in differentiated 3T3-L1 cells. The GLAB, Lactobacillus plantarum LG42, significantly decreased the intracellular triglyceride storage and the glycerol-3-phosphate dehydrogenase $(\mathrm{GPDH})$ activity in a dose-dependent manner. mRNA expression of transcription factors like peroxisome proliferator-activated receptor (PPAR) $\gamma$ and CCAAT/enhancer-binding protein (C/EBP) $\alpha$ involved in adipogenesis was markedly decreased by the GLAB treatment. Moreover, the GLAB also decreased the expression level of adipogenic markers like adipocyte fatty acid binding protein (aP2), leptin, GPDH, and fatty acid translocase (CD36) significantly. These results suggest that the GLAB inhibits lipid accumulation in the differentiated adipocyte through downregulating the expression of adipogenic transcription factors and other specific genes involved in lipid metabolism.
\end{abstract}

\section{Introduction}

Gajami sik-hae is a fermented fish product popular in the northeastern coastal area of Korea. Sik-hae is a traditional Korean fermented seafood and has long been used for seasoning and is the generic name for a class of Korean lactic acid fermented fish products [1]. It is prepared through blending of various kinds of seafood, including cooked rice, red pepper, radish, garlic, ginger, malt meal, and salt, that becomes palatable through the subsequent preservation and fermentation [2]. The unique taste of sik-hae is due to the presence of the aforementioned ingredients and also due to the fermenting action of various microorganisms during the fermentation period [3]. Lactic acid bacteria (LAB) are the most predominant microorganisms involved in sik-hae fermentation. Some LABs were isolated from fish fermented food in Korea [4]. LAB is a viable bacteria that beneficially influence the health of the host. Recently, LAB has been revaluated for their nutritional, physiological, and pharmacological aspects, which have raised attention towards the functional effect of Korean traditional foods including kimchi and joet-gal [5].
Various nutritional and therapeutic effects ascribed to LAB in the human body are the metabolic stimulation of vitamin synthesis and enzyme production, antimutation, anticancer, gastric secretomotor, and immune function [6].

Nowadays, the consumer pays a lot of attention in looking for the relation between food and its health benefit. As a consequence, the market for foods with health-promoting properties, the so-called functional foods, has shown a remarkable growth over the past few years [7]. The development of food, which utilizes the functionality and effectiveness of probiotics, has been officially recognized as an important field of study. Consequently, numerous studies for using probiotic organisms as a functional food have been investigated. Earlier studies on probiotics have been brought into effect on the stabilization of gastrointestinal microflora, the reduction of saprogenic products, the prevention of degenerative disease, activation of the immune system, anticancer activities, antiobesity, lowering of cholesterol, and the suppression and prevention of constipation [8-12].

$\gamma$-Aminobutyric acid (GABA) is a four-carbon nonprotein amino acid conserved from bacteria to plants and 
vertebrates. It was discovered in plants more than half a century ago, but the interest in GABA shifted to animals when it was revealed that GABA occurs at high levels in the brain, playing a major role in neurotransmission [13]. The pathway for GABA synthesis is composed of the cytosolic enzyme glutamate decarboxylase (GAD) and the mitochondrial enzymes GABA transaminase (GABA-T) and succinic semialdehyde dehydrogenase (SSADH) [14]. The consumption of GABA-enriched foods such as milk, soybean, and gabaron tea has been reported to suppress the elevation of systolic blood pressure in spontaneously hypertensive rats (SHRs) [15-17]. In this study, isolated LAB with GABA producing ability from traditional Korean fermented foods such as kimchi [18] and sik-hae (S.H. Oh). The isolated LABs were Lactobacillus brevis OPK-3, Lactobacillus sakei OPK2-59, and Lactobacillus plantarum LG42. Therefore, it was our interest to find whether the isolated LAB can be a novel nutraceuticals. This study was carried out with the objective of testing the antiobesity property of Lactobacillus plantarum LG42 (GLAB) with GABA producing ability. Our finding reveals the inhibitory effect of the GLAB on adipocyte differentiation through modulating the expression of adipogenic transcription factors and other adipogenesis specific genes, suggesting the antiobesity property of GLAB.

\section{Materials and Methods}

2.1. Cell Culture. 3T3-L1 cells (American Type Culture Collection (ATCC)) were cultured in DMEM containing high glucose supplemented with $10 \%$ fetal bovine serum (FBS) and penicillin/streptomycin in 6 well culture plates. Two days after confluence cells were cultured in the adipocyte differentiation cocktail media containing $5 \mathrm{mM} 3$-isobutyl1-methylxanthine (IBMX), 1 mM dexamethasone (Sigma, USA), and insulin (10 mg/mL) in DMEM supplemented with $10 \%$ fetal bovine serum (FBS) for 2 days. The differentiation was complete after 6 days.

2.2. GLAB Sample and Treatment. L. plantarum LG42, a lactic acid bacteria having GABA producing capacity, isolated from gajami sik-hae (GLAB), was supplied by Woosuk University, genetic engineering laboratory, Korea. For TLC (thin layer chromatography) analysis, silica gel 60 F254 (Merck, Germany), standard GABA (Sigma, USA), solvent mixture (butanol: acetic acid: dichloromethanol: water in $5: 3: 3: 3$ ratio) were used. The cultured medium, cell-free supernatant, and cytoplasmic fraction samples $(0.3 \mu \mathrm{L}$ each) were spotted 3 times. The GLAB was incubated at $37^{\circ} \mathrm{C}$ for $16 \sim 18 \mathrm{hr}$ in MRS agar plates (Difco, Detroit, USA). All purified strains were kept at $-70^{\circ} \mathrm{C}$ until use. After culturing the GLAB, all strains were harvested in a refrigerated centrifuge $(1,100 \times \mathrm{g}$ for $3 \mathrm{~min}$ at $4^{\circ} \mathrm{C}$ ) and washed three times with distilled water for the removal of MRS broth. The washed GLAB was freezedried and resuspended in distilled water at a concentration of $10 \mathrm{mg} / \mathrm{mL}$ and homogenized for $50 \mathrm{sec}$ followed by $1 \mathrm{~min}$ rest (repeated 3 times) using a sonicator (Fisher Scientific Co., Toronto, ON, USA). The suspension was centrifuged at $1,100 \times \mathrm{g}$ for $15 \mathrm{~min}$ at $4^{\circ} \mathrm{C}$. The 3T3-L1 cells were treated with five different concentrations of the supernatant, that is, 0 (control), 10, 20, 30, and $40 \mu \mathrm{g} / \mathrm{mL}$.

2.3. Oil Red O Staining of 3T3-L1 Adipocyte. Intracellular lipid accumulation was measured using oil red O (Sigma, St. Louis, MO). 3T3-L1 cells were fixed with 3.7\% formaldehyde/PBS and stained with oil red O. Quantification of lipid accumulation was achieved by oil red $\mathrm{O}$ from stained cells with isopropyl alcohol and measured spectrophotometrically at $510 \mathrm{~nm}$. The oil red $\mathrm{O}$ stained material was expressed on a per cell basis using the cell number determined from similar plates. The percentage of oil red $\mathrm{O}$ stained material relative to control wells containing cell culture medium without compounds was calculated as $A_{510 \mathrm{~nm}}(\mathrm{GLAB}) / A_{510 \mathrm{~nm}}$ (control) $\times 100$.

2.4. Triglyceride Content. Triglyceride content was determined using a commercial triglyceride assay kit (Zen-bio, Research Triangle Park, NC), according to the manufacturer's protocol. The protein concentration was determined by using a Bradford reagent (Sigma, St. Louis, MO).

2.5. Glycerol-3-Phosphate Dehydrogenase Activity. GPDH was measured by following the disappearance of NADH during enzyme-catalysed dihydroxyacetone phosphate reduction using the GPDH activity assay kit (TAKARA BIO INC., Japan). GPDH activity was spectrophotometrically determined at $340 \mathrm{~nm}$. One unit was defined as the amount of enzyme required for the consumption of $1 \mu \mathrm{mol}$ of $\mathrm{NADH}$ for one minute at $30^{\circ} \mathrm{C}$. The enzyme activity was calculated with the following formula: GPDH activity (units $/ \mathrm{mL}$ ) = $\left(\Delta \mathrm{OD}_{340} \times A(\mathrm{~mL}) \times\right.$ dilution ratio of the test sample $) /(6.22$ $\times B(\mathrm{~mL}) \times C(\mathrm{~cm}))$.

$\Delta \mathrm{OD}_{340}$ : decrease in the absorbance at $340 \mathrm{~nm}$ per minute.

$A(\mathrm{~mL})$ : total reaction volume.

$B$ (mL): the volume of enzyme solution (diluted sample) added.

$C(\mathrm{~cm})$ : optical path length of the cell used*.

6.22: millimolar absorption coefficient of $\mathrm{NADH}$ molecules.

2.6. Quantitative Real-Time PCR Analysis. Total RNA was extracted from 3T3-L1 cells at various times after adipogenic induction using Trizol reagent (Invitrogen Life Technologies; Carlsbad, CA, USA) and the concentration measured spectrophotometrically. The extracted RNA was reverse transcribed into complementary DNA using a high capacity cDNA reverse transcription kit (Applied Biosystems, Foster City, CA, USA). Then the RNA expression level was quantified by a quantitative real-time PCR using SYBR Green PCR Master Mix (Applied Biosystems, Woolston, Warrington, UK) and the 7500 real-time PCR system (Applied Biosystems, Foster City, CA, USA) according to the manufacture's protocol. The Sequences of primers used for quantitative real-time PCR are as follows: fatty acid binding protein (aP2) 
F: $5^{\prime}$-AGTGAAAACTTCGATGATTACATGAA- $3^{\prime}$ and R: $5^{\prime}$-GCCTGCCACTTTCCTTGTG-3'; fatty acid translocase (CD36) F: $5^{\prime}$-TTGTACCTATACTGTGGCTAAATGAGA$3^{\prime}$ and R: $5^{\prime}$-CTTGTGTTTTGAACATTTCTGCTT- $3^{\prime}$; CCAAT/enhancer-binding protein $\alpha(\mathrm{C} / \mathrm{EBP} \alpha)$ F: $5^{\prime}$ AGCAACGAGTACCGGGTACG-3' and R: $5^{\prime}$-TGTTTGGCTTTATCTCGGCTC- ${ }^{\prime}$; peroxisome proliferator-activated receptor $\gamma(\operatorname{PPAR} \gamma)$ F: $5^{\prime}$-CAAGAATACCAAAGTGCGATCAA-3 $3^{\prime}$ and R: $5^{\prime}$-GAGCTGGGTCTTTTCAGAATAATAAG-3'; (leptin) F: $5^{\prime}$-CCGCCAAGCAGAGGGTCAC- $3^{\prime}$ and R: $5^{\prime}$-GCATTCAGGGCTAACATCCAACT- ${ }^{\prime}$; glycerol-3-phosphate dehydrogenase(GPDH) F: $5^{\prime}$-CTCTTCTTGCCGCTTCAGTTT- ${ }^{\prime}$ and R: $5^{\prime}$-CATGTAGGCCATGAGGTCCACCAC- $3^{\prime}$; $\beta$-actin F: $5^{\prime}$-ATGGATGACGATATCGCT- $3^{\prime}$ and R: $5^{\prime}$-ATGAGGTAGTCTGTCAGGT- $3^{\prime}$. Relative quantification of gene expression with real-time PCR data was calculated relative to $\beta$-actin.

2.7. Analysis of GABA Production. GABA formation in cultured medium and cytoplasmic fraction of $L$. plantarum LG42 cells were analyzed by TLC as described (25). In order to produce GABA in the culture medium, $1 \%$ MSG was added to MRS broth and then cultured for $48 \mathrm{~h}$ at $30^{\circ} \mathrm{C}$, and verified the existence or nonexistence of GABA in the bacterial cytoplasmic fraction by using TLC.

2.8. Statistical Analysis. All values are expressed as mean \pm $\mathrm{SD}$. The data were analyzed by one-way ANOVA using SPSS version 16.0. The differences among groups were assessed using Duncan's multiple range test. Statistical significance was considered at $P$ value $<0.05$.

\section{Results}

3.1. Oil Red O Staining and Intracellular Triglyceride. The effects of GLAB on oil red O stained 3T3-L1 adipocyte are shown in Figure 1. Cells treated with $10 \mu \mathrm{g}$ and $20 \mu \mathrm{g}$ concentrations did not show any significant effects compared with untreated cells. Differentiated cells treated with $30 \mu \mathrm{g}$ of GLAB accumulated about a 30\% decrease in intracellular lipid compared to control. Also, the treatment with $40 \mu \mathrm{g}$ GLAB resulted in further reduction to approximately $58 \%$ of the lipid accumulation of the control.

The effect of GLAB on the inhibition of intracellular triglyceride in 3T3-L1 adipocyte is shown in Figure 2. The results demonstrated that GLAB caused an inhibition on intracellular triglyceride accumulation. Especially, $40 \mu \mathrm{g}$ of GLAB treatment, which was most effective compared with $10 \mu \mathrm{g}$ treated and untreated cells (Figure 2).

3.2. Measurement of GPDH Activity. The effects of GLAB on GPDH activity in 3T3-L1 adipocyte are shown in Figure 3. GPDH activity, which indicates the late phase of adipocyte differentiation, was also determined. The effect of GLAB on adipogenesis was clearly dose dependent. The high dose, 30 and $40 \mu \mathrm{g}$, of GLAB significantly decreased GPDH activity (Figure 3).
3.3. mRNA Expression of Lipid Metabolism-Related Gene in Differentiated 3T3-L1 Adipocyte. PPAR $\gamma$ and C/EBP $\alpha$ mRNA levels in differentiated 3T3-L1 adipocyte were significantly decreased in cells treated with GLAB compared with untreated cell, especially $40 \mu \mathrm{g}$ treated cell was most effective (Figure 4). In addition, the expression of PPAR $\gamma$ target gene, aP2 was significantly decreased in GLAB treated cells, and CD 36 was significantly decreased in 20,30 , and $40 \mu \mathrm{g}$ treated cells compared with untreated cell during adipocyte differentiation (Figure 4). Cells treated with GLAB resulted in a significant decrease in the mRNA levels of leptin compared to cell untreated with GLAB. The GPDH mRNA level was significantly decreased in 30 and $40 \mu \mathrm{g} / \mathrm{mL}$ treated cells compared with $10 \mu \mathrm{g} / \mathrm{mL}$ treated and untreated cells.

3.4. GABA Production by L. plantarum LG42. GABA production by $L$. plantarum LG42 strain was studied in MRS broth containing 1\% MSG. Based on the TLC analysis data, the cultured medium and cell-free culture supernatant of L. plantarum LG42 cells contained GABA, but not the cytoplasmic fraction (Figure 5). This data indicated that $L$. plantarum LG42 cells have GABA producing ability and the GABA was excreted mainly in the cell culture medium.

\section{Discussion}

Obesity threatens to become the 21st century's leading metabolic disease in the world [19]. Complications associated with obesity are responsible for the most obesity related morbidity and mortality. Obesity increases circulating cholesterol and triglyceride levels and is closely associated with hypertension, cardiovascular disease, type 2 diabetes mellitus, cancer, respiratory complications, and osteoarthritis [20]. Obesity is a condition in which adipocytes not only accumulate a large amount of fat, but also become enlarged. At a cellular level, it is characterized by an increase in the number and size of adipocytes differentiated from fibroblastic preadipocytes in the adipose tissue [21]. The severity of obesity is correlated with the degree of differentiation of preadipocytes to adipocytes and the enlargement of adipocytes in adipose tissues [22]. PPAR $\gamma$ and $\mathrm{C} / \mathrm{EBP} \alpha$ are transcriptional activators, which play a major role in coordinating the adipocyte gene expression during adipocyte differentiation [23]. Therefore, we investigated the effects of lactic acid bacteria isolated gajami sik-hae (GLAB) on the differentiation of 3T3-L1 cells to clarify its antiobesity mechanism. GLAB significantly suppressed lipid accumulation in 3T3-L1 cells in a nontoxic concentration. GPDH activity was decreased in 3T3-L1 cells treated with GLAB compared to control cells incubated in the differentiation medium (Figure 3$)(P<0.05)$. GPDH is a key enzyme important for triacylglycerol synthesis [24], the present result indicates that GLAB suppresses adipocyte differentiation resulted in reducing GAPDH level.

It is noteworthy that $\mathrm{PPAR} \gamma$ and $\mathrm{C} / \mathrm{EBP} \alpha$ levels were downregulated in 3T3-L1 cells treated with GLAB (Figure 4). $\operatorname{PPAR} \gamma$ and $\mathrm{C} / \mathrm{EBP} \alpha$ play vital roles in the early stage of adipose differentiation [25]. PPAR $\gamma$ and C/EBP $\alpha$ regulate the expression of adipogenic genes such as CD36, leptin, 

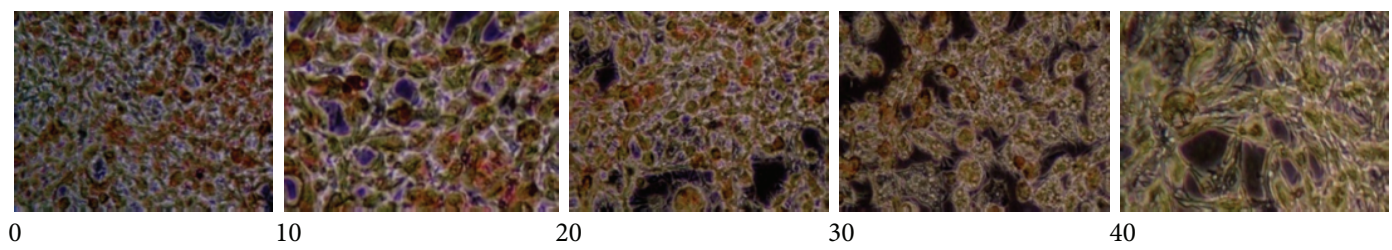

$(\mu \mathrm{g} / \mathrm{mL})$

(a)

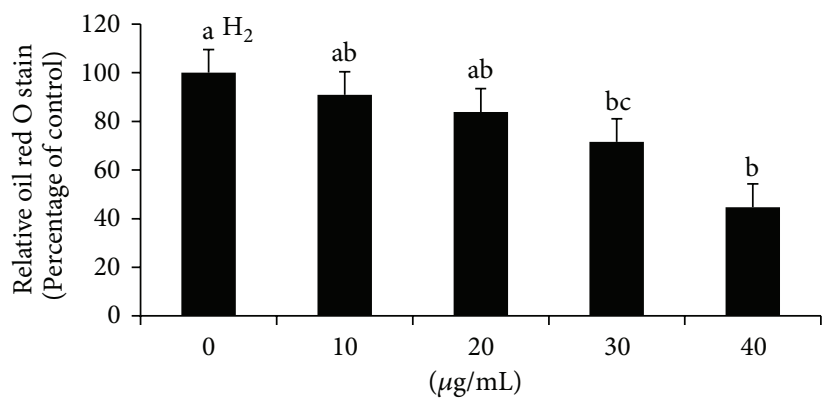

(b)

FIgURE 1: The effect of lactic acid bacteria isolated gajami sik-hae on oil red O stained in 3T3-L1 adipocyte (a) Photograph of oil red O staining. (b) Quantification of oil red O staining. Values with different superscripts are significantly different by ANOVA with Duncan's multiple range tests at $P<0.05$.

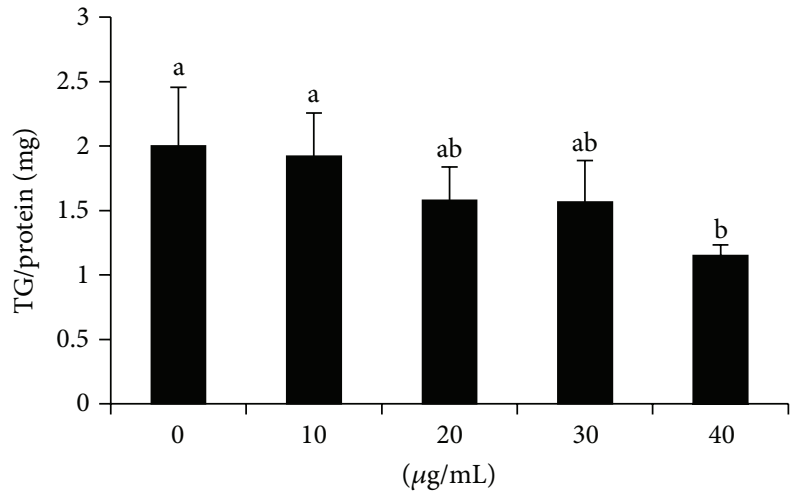

FIGURE 2: The effect of lactic acid bacteria isolated gajami sik-hae on triglyceride accumulation in 3T3-L1 adipocyte. Values with different superscripts are significantly different by ANOVA with Duncan's multiple range tests at $P<0.05$.

GPDH, and aP2 triggering the accumulation of fat in the cells $[26,27]$. In this study, the expression of PPAR $\gamma$ and $\mathrm{C} / \mathrm{EBP} \alpha$ was inhibited by GLAB together resulting in reduced adipogenesis indirectly confirmed by measuring oil red stain and GPDH activity. Therefore, it appears that GLAB inhibits adipogenesis by reducing or suppressing the expression of PPAR $\gamma$ and $\mathrm{C} / \mathrm{EBP} \alpha$ levels. It is also reasonable to articulate that GLAB acts directly on PPAR $\gamma$ and $\mathrm{C} / \mathrm{EBP} \alpha$. Kim et al. (2008) showed that treating 3T3-L1 cells with milk fermented with lactic acid bacteria isolated from kimchi decreased the levels of PPAR $\gamma$ and C/EBP- $\alpha$ expression [28]. Thus, it could be possible that lactic acid bacteria isolated from gajami sikhae affects the downstream genes of PPAR $\gamma$ and $\operatorname{C/EBP} \alpha$, thus inhibiting adipogenesis in 3T3-L1 cells.

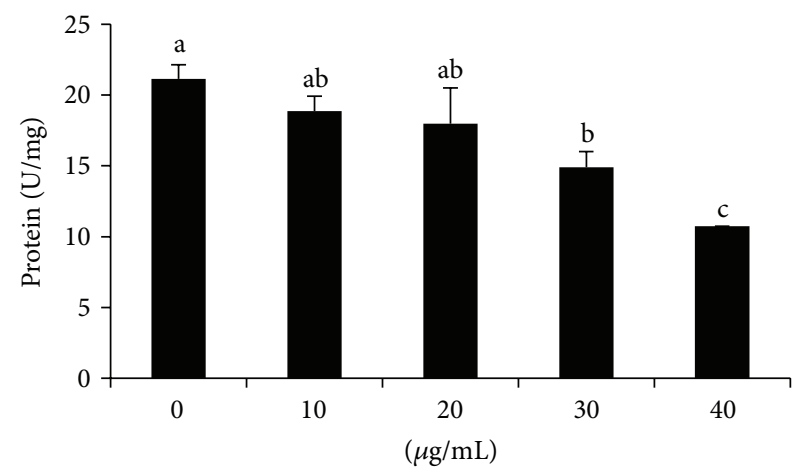

FIGURE 3: The effect of lactic acid bacteria isolated gajami sikhae on GPDH activity in 3T3-L1 adipocyte. Values with different superscripts are significantly different by ANOVA with Duncan's multiple range tests at $P<0.05$.

aP2 gene is central to the pathway that links obesity to insulin resistance, possibly by linking fatty acid metabolism to the expression of (tumor necrosis factor- $\alpha$ ) TNF- $\alpha[29,30]$. CD36 mRNA expression is activated during 3T3-L1 adipocyte differentiation, and CD36 protein levels are positively correlated with $\operatorname{PPAR} \gamma$ and $\mathrm{C} / \mathrm{EBP} \alpha$ [31]. CD36 is a long chain fatty acid transporter present on the plasma membrane, as well as in intracellular pools of the skeletal muscle [32]. High level CD36 might result in lipid accumulation, which is supported by studies using CD36 null mice [33]. Leptin, a hormone and the product of the $o b$ gene, is primarily secreted by adipose tissue. It is involved in the regulation of energy expenditure and food intake [34]. The expression of leptin is regulated by several substances like insulin, glucocorticoids, and TNF- $\alpha$. Here in this study, we found that aP2, CD36, and 


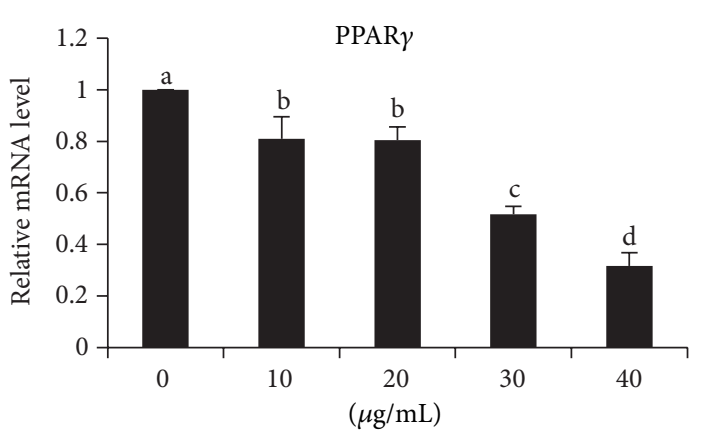

(a)

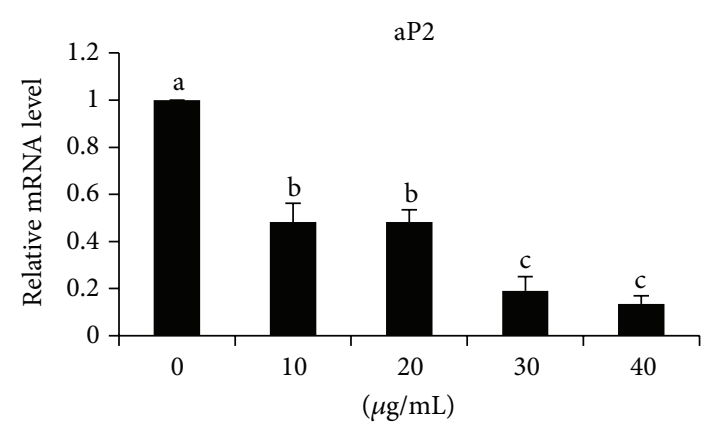

(c)

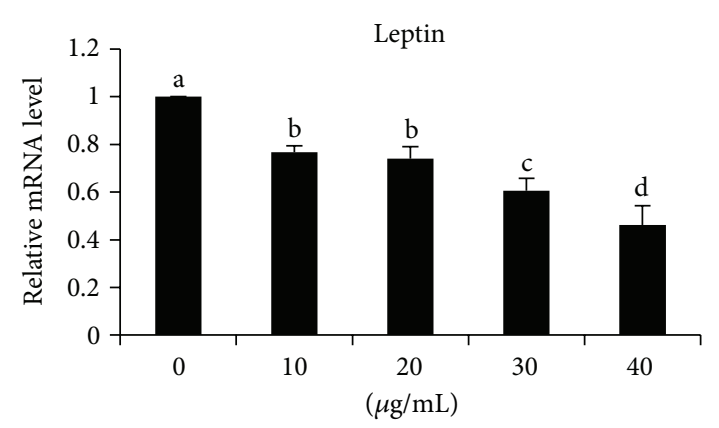

(e)

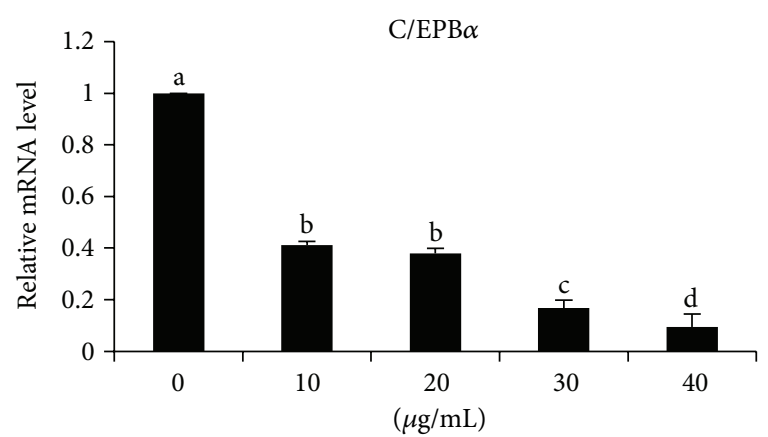

(b)

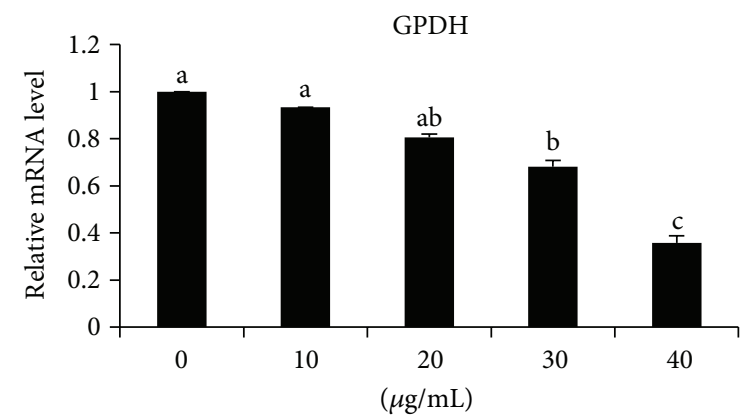

(d)

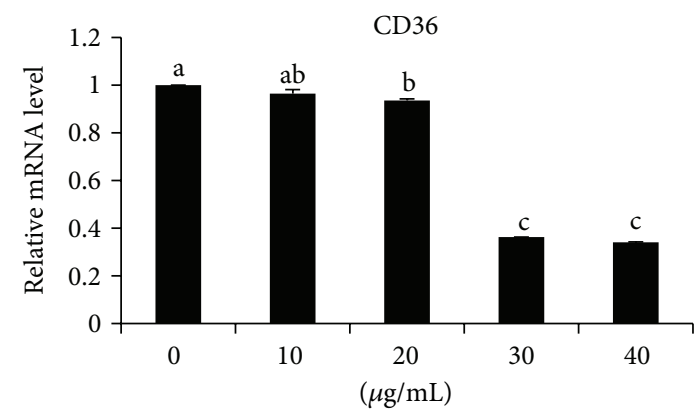

(f)

FIGURE 4: The effect of lactic acid bacteria isolated gajami sik-hae on mRNA levels of PPAR $\gamma, \mathrm{C} / \mathrm{EBP} \alpha$, aP2, GPDH, leptin, and CD36 in 3T3-L1 cells. Values with different superscripts are significantly different by ANOVA with Duncan's multiple range tests at $P<0.05$. Peroxisome proliferator-activated receptor $\gamma(\mathrm{PPAR} \gamma)$; CCAAT/enhancer-binding protein $\alpha(\mathrm{C} / \mathrm{EBP} \alpha)$; fatty acid binding protein (aP2); glycerol-3-phosphate dehydrogenase(GPDH); fatty acid translocase (CD36).

leptin mRNA expressions were inhibited by GLAB (Figure 4). aP2, CD36, and leptin are the target genes of C/EBP $\alpha$ and PPAR $\gamma$ and are regulated by these transcription factors. Thus, our results suggest that the inhibition of adipogenic gene expression induced by GLAB may be mediated by the inhibition of $\mathrm{C} / \mathrm{EBP} \alpha$ and PPAR $\gamma$ expression.

Gajami sik-hae is a fermented food containing many kinds of microorganisms, with Lactobacillus and Streptococcaceae as the dominant species [35]. Lactobacillus and Leuconostoc species among lactobacillus produces various materials by proliferation, fermentation, and metabolism. Functional organic acids like lactic acid and citric acids are the major products of fermentation by these bacteria. Functional materials such as acetylcholine, dextran, bacteriocin, and $\gamma$-aminobutyric acid are also produced by these microbes depending on the origin of the fermenting materials. The fermenting materials containing carotenoids, ascorbic acids, phenolic compounds, and amino acids play a major role in this process $[18,36]$. Among the various beneficial health effects of the probiotics $[37,38]$, their biological impact on obesity has generated a considerable interest. Regarding the anti-obesity property of probiotics, some reports demonstrated that dairy products fermented with lactic acid bacteria exert anti-obesity effects $[28,39,40]$. Previously, it has been shown that cytoplasmic fractions of useful LAB have some beneficial effects for the improvement of health related symptoms [41, 42]. Among various compounds from $\mathrm{LAB}$ contributing to anti-obesity effects and improving lipid profiles are conjugated linoleic acid (CLA), ornithine, GABA, hydroxy methyl glutaric acid, orotic acid, and so forth [18, 43-46]. Although GABA can exert an antiobesity effect and the GLAB has GABA producing capacity 


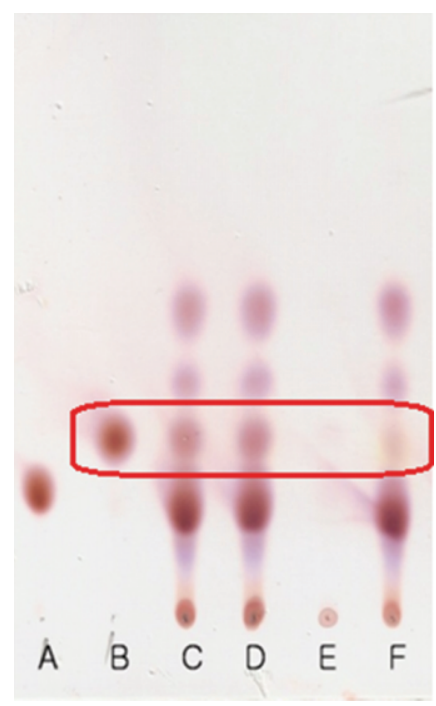

Figure 5: TLC analysis of GABA in the culture medium and cytoplasmic fraction of L. plantarum LG42 cells. A: spot of standard MSG; B: spot of standard GABA; C-E: spots of cell culture medium (C), cell-free supernatant (D), and cytoplasmic fraction of cells (E) cultured in MRS broth with 1\% MSG; F: spot of cell culture medium cultured without added MSG.

and since the cytoplasmic fraction used in this study contains a negligible amount of GABA (Figure 5), it is not clear what compounds of GLAB worked as the main principles of the anti-obesity effects. Therefore, GLAB having GABA producing ability can be used as a useful material not only for the production of fermented foods such as sik-hae with an enhanced level of GABA, but also for the investigation of unknown compounds except GABA for the anti-obesity effects. Further studies are required to identify the active compounds of GLAB that have specific effects on obesity.

In conclusion, the inhibitory effects of GLAB on 3T3L1 adipocyte, as indicated by a decrease in intracellular triglyceride content and GPDH activity have been elucidated. It appears to be mediated through downregulating the expression of adipogenic transcription factor, PPAR $\gamma$ and $\mathrm{C} / \mathrm{EBP} \alpha$, and adipocyte-specific gene such as aP2, leptin, GPDH, and CD36. These results indicate that GLAB may play a role in the control of adipogenesis and might have further implication for in vivo antiobesity effect.

\section{Conflict of Interests}

The authors declare that they have no conflict of interests.

\section{Acknowledgments}

This paper was supported by the Globalization of Korean Foods R\&D program (Grant no. 911049-1), funded by the Ministry of Food, Agriculture, Forestry and Fisheries, Republic of Korea. The authors thank NUC Electronics Co., Ltd., for their assistance.

\section{References}

[1] H. S. Jung, S. H. Lee, and K. L. Woo, "Effect of salting levels on the changes of taste constituents of domestic fermented flounder sikhae of Hamkyeng-Do," Journal of Food Science and Biotechnology, vol. 24, no. 1, pp. 59-64, 1992.

[2] J. H. Yoon, S. S. Kang, K. C. Lee et al., "Bacillus jeotgali $s p$. nov., isolated from jeotgal, Korean traditional fermented seafood," International Journal of Systematic and Evolutionary Microbiology, vol. 51, no. 3, pp. 1087-1092, 2001.

[3] C. H. Lee, "Lactic acid fermented foods and their benefits in Asia," Food Science and Biotechnology, vol. 5, no. 3, pp. 187-197, 1996.

[4] H. J. Lee, Y. J. Joo, C. S. Park et al., "Purification and characterization of a bacteriocin produced by Lactococcus lactis subsp, lactis H-559 isolated from kimchi," Journal of Bioscience and Bioengineering, vol. 88, no. 2, pp. 153-159, 1999.

[5] S. J. Kim, "Potential probiotic properties of lactic acid bacteria isolated from kimchi," Food Science and Biotechnology, vol. 14, no. 4, pp. 547-550, 2005.

[6] A. S. Naidu, W. R. Bidlack, and R. A. Clemens, "Probiotic spectra of lactic acid bacteria (LAB)," Critical Reviews in Food Science and Nutrition, vol. 39, no. 1, pp. 13-126, 1999.

[7] F. Leroy and L. De Vuyst, "Lactic acid bacteria as functional starter cultures for the food fermentation industry," Trends in Food Science \& Technology, vol. 15, no. 2, pp. 67-78, 2004.

[8] B. Goldin and S. L. Gorbach, "Alterations in fecal microflora enzymes related to diet, age, lactobacillus supplements, and dimethylhydrazine," Cancer, vol. 40, no. 5, pp. 2421-2426, 1977.

[9] S. E. Gilliland and D. K. Walker, "Factors to consider when selecting a culture of Lactobacillus acidophilus as a dietary adjunct to produce a hypocholesterolemic effect in humans," Journal of Dairy Science, vol. 73, no. 4, pp. 905-911, 1990.

[10] R. Fuller, "Probiotics in human medicine," Gut, vol. 32, no. 4, pp. 439-442, 1991.

[11] H. Poo, H. M. Pyo, T. Y. Lee et al., "Oral administration of human papillomavirus type 16 E7 displayed on Lactobacillus casei induces E7-specific antitumor effects in C57/BL6 mice," International Journal of Cancer, vol. 119, no. 7, pp. 1702-1709, 2006.

[12] H. Y. Lee, J. H. Park, S. H. Seok et al., "Human originated bacteria, Lactobacillus rhamnosus PL60, produce conjugated linoleic acid and show anti-obesity effects in diet-induced obese mice," Biochimica et Biophysica Acta, vol. 1761, no. 7, pp. 736744, 2006.

[13] P. Krogsgaard-Larsen, "GABA receptors," in Receptor Phamacology and Function, M. Williams, R. A. Glennon, and P. M. W. M. Timmermans, Eds., pp. 349-383, Marcel Dekker, New York, NY, USA, 1989.

[14] B. V. Manyam, L. Katz, T. A. Hare, K. Kaniefski, and R. D. Tremblay, "Isoniazid-induced elevation of CSF GABA levels and effects on chorea in Huntington's disease," Annals of Neurology, vol. 10, no. 1, pp. 35-37, 1981.

[15] C. F. Liu, Y. T. Tung, C. L. Wu, B. H. Lee, W. H. Hsu, and T. M. Pan, "Antihypertensive effects of Lactobacillus-fermented milk orally administered to spontaneously hypertensive rats," Journal of Agricultural and Food Chemistry, vol. 59, no. 9, pp. 4537-4543, 2011.

[16] M. Omori, T. Yano, J. Okamoto, T. Tsushida, T. Murai, and M. Higuchi, "Effect of anaerobic treated tea (Gabaron Tea) on blood pressure of spontaneously hypertensive rats," Journal of 
the Agricultural Chemical Society of Japan, vol. 61, no. 11, pp. 1449-1451, 1987.

[17] H. Aoki, Y. Furuya, Y. Endo, and K. Fujimoto, "Effect of $\gamma$ aminobutyric acid-enriched tempeh-like fermented soybean (GABA-tempeh) on the blood pressure of spontaneously hypertensive rats," Bioscience, Biotechnology and Biochemistry, vol. 67, no. 8, pp. 1806-1808, 2003.

[18] M. O. Bae, H. J. Kim, Y. S. Cha, M. K. Lee, and S. H. Oh, "Effects of Kimchi lactic acid bacteria Lactobacillus sp. OPK259 with high GABA producing capacity on liver function improvement," Journal of the Korean Society of Food Science and Nutrition, vol. 38, no. 11, pp. 1499-1505, 2009.

[19] Formiguera and A. Cantón, "Obesity: epidemiology and clinical aspects," Best Practice \& Research Clinical Gastroenterology, vol. 18, no. 6, pp. 1125-1146, 2004.

[20] P. G. Kopelman, "Obesity as a medical problem," Nature, vol. 404, no. 6778, pp. 635-643, 2000.

[21] T. Furuyashiki, H. Nagayasu, Y. Aoki et al., "Tea catechin suppresses adipocyte differentiation accompanied by downregulation of PPAR $\gamma 2$ and $\mathrm{C} / \mathrm{EBP} \alpha$ in 3T3-L1 cells," Bioscience, Biotechnology, and Biochemistry, vol. 68, no. 11, pp. 2353-2359, 2004.

[22] Y. W. Wang and P. J. Jones, "Conjugated linoleic acid and obesity control: efficacy and mechanisms," International Journal of Obesity and Related Metabolic Disorders, vol. 28, no. 8, pp. 941-955, 2004.

[23] X. Guo and K. Liao, "Analysis of gene expression profile during 3T3-L1 preadipocyte differentiation," Gene, vol. 251, no. 1, pp. 45-53, 2000.

[24] L. S. Wise and H. Green, "Participation of one isozyme of cytosolic glycerophosphate dehydrogenase in the adipose conversion of 3T3 cells," The Journal of Biological Chemistry, vol. 254, no. 2, pp. 273-275, 1979.

[25] E. D. Rosen, C. J. Walkey, P. Puigserver, and B. M. Spiegelman, "Transcriptional regulation of adipogenesis," Genes and Development, vol. 14, no. 11, pp. 1293-1307, 2000.

[26] J. Berger and D. E. Moller, "The mechanisms of action of PPARs," Annual Review of Medicine, vol. 53, pp. 409-435, 2002.

[27] T. Kawada, N. Takahashi, and T. Fushiki, "Biochemical and physiological characteristics of fat cell," Journal of Nutritional Science and Vitaminology, vol. 47, no. 1, pp. 1-12, 2001.

[28] N. H. Kim, P. D. Moon, S. J. Kim et al., "Lipid profile lowering effect of Soypro fermented with lactic acid bacteria isolated from Kimchi in high-fat diet-induced obese rats," BioFactors, vol. 33, no. 1, pp. 49-60, 2008.

[29] P. Tontonoz, E. Hu, R. A. Graves, A. I. Budavari, and B. M. Spieglman, "mPPAR gamma 2: tissue-specific regulator of an adipocyte enhancer," Genes and Development, vol. 8, no. 10, pp. 1224-1234, 1994.

[30] G. S. Hotamisligil, R. S. Johnson, R. J. Distel, R. Ellis, V. E. Papaioannou, and B. M. Spiegelman, "Uncoupling of obesity from insulin resistance through a targeted mutation in aP2, the adipocyte fatty acid binding protein," Science, vol. 274, no. 5291, pp. 1377-1379, 1996.

[31] L. Qiao, C. Zou, P. Shao, J. Schaack, P. F. Johnson, and J. Shao, "Transcriptional regulation of fatty acid translocase/CD36 expression by CCAAT/enhancer-binding protein $\alpha$," The Journal of Biological Chemistry, vol. 283, no. 14, pp. 8788-8795, 2008.

[32] H. Muller, K. Deckers, and J. Eckel, “The fatty acid translocase (FAT)/CD36 and the glucose transporter GLUT4 are localized in different cellular compartments in rat cardiac muscle,"
Biochemical and Biophysical Research Communications, vol. 293, no. 2, pp. 665-669, 2002.

[33] B. I. Frohnert, T. Y. Hui, and D. A. Bernlohr, "Identification of a functional peroxisome proliferator-responsive element in the murine fatty acid transport protein gene," The Journal of Biological Chemistry, vol. 274, no. 7, pp. 3970-3977, 1999.

[34] D. S. Weigle, T. R. Bukowski, D. C. Foster et al., "Recombinant $\mathrm{ob}$ protein reduces feeding and body weight in the ob/ob mouse," The Journal of Clinical Investigation, vol. 96, no. 4, pp. 2065-2070, 1995.

[35] H. J. Lee and W. J. Kim, "Isolation and characterization of antilisterial and amylase sensitive enterocin producing Enterococcus faecium DB1 from gajami-sikhae, a fermented flat fish in Korea," Food Science and Biotechnology, vol. 19, no. 2, pp. 373-381, 2010.

[36] K. Y. Park and H. S. Cheigh, "Antimutagenic and anticancer effects of lactic acid bacteria isolated from Kimchi," Bioindustry News, vol. 13, no. 3, pp. 11-17, 2000.

[37] J. Schrezenmeir and M. de Vrese, "Probiotics, prebiotics, and synbiotics-approaching a definition," The American Journal of Clinical Nutrition, vol. 73, no. 2, supplement, pp. 361S-364S, 2001.

[38] F. P. J. Martin, Y. Wang, N. Sprenger et al., "Probiotic modulation of symbiotic gut microbial-host metabolic interactions in a humanized microbiome mouse model," Molecular Systems Biology, vol. 4, article 157, 2008.

[39] K. Manabu and H. Fang, "Anti-obesity effects of probiotics in fermented milk," Journal of Intestinal Microbiology, vol. 24, no. 4, pp. 265-271, 2010.

[40] J. Z. Xiao, S. Kondo, N. Takahashi et al., "Effects of milk products fermented by Bifidobacterium longum on blood lipids in rats and healthy adult male volunteers," Journal of Dairy Science, vol. 86, no. 7, pp. 2452-2461, 2003.

[41] M. Thirabunyanon, P. Boonprasom, and P. Niamsup, "Probiotic potential of lactic acid bacteria isolated from fermented dairy milks on antiproliferation of colon cancer cells," Biotechnology Letters, vol. 31, no. 4, pp. 571-576, 2009.

[42] H. J. Hur, K. W. Lee, H. Y. Kim, D. K. Chung, and H. J. Lee, “In vitro immunopotentiating activities of cellular fractions of lactic acid bacteria isolated from Kimchi and bifidobacteria," Journal of Microbiology and Biotechnology, vol. 16, no. 5, pp. 661-666, 2006.

[43] Y. J. Moon, J. R. Soh, J. J. Yu, H. S. Sohn Y. S, Cha, and S. H. Oh, "Intracellular lipid accumulation inhibitory effect of Weissella koreensis OK1-6 isolated from Kimchi on differentiating adipocyte," Journal of Applied Microbiology, vol. 113, no. 3, pp. 652-658, 2012.

[44] J. R. Soh, N. S. Kim, C. H. Oh, S. H. Oh, and Y. S. Cha, "Carnithine and/or GABA supplementation increases immune function and changes lipid profiles and some lipid soluble vitamins in mice chronically administered alcohol," Journal of Food Science and Nutrition, vol. 15, no. 3, pp. 196-205, 2010.

[45] Y. G. An, "Probiotic lactic acid bacteria," Journal of Korean Society of Food Science and Nutrition, vol. 24, no. 4, pp. 817-832, 2011.

[46] Y. Xu, G. O. William, C. C. Lee, G. M. Martin, and T. Qingchun, "Role of GABA release from leptin receptor-expressing neurons in body weight regulation," Endocrinology, vol. 153, no. 5, pp. 2223-2233, 2012. 

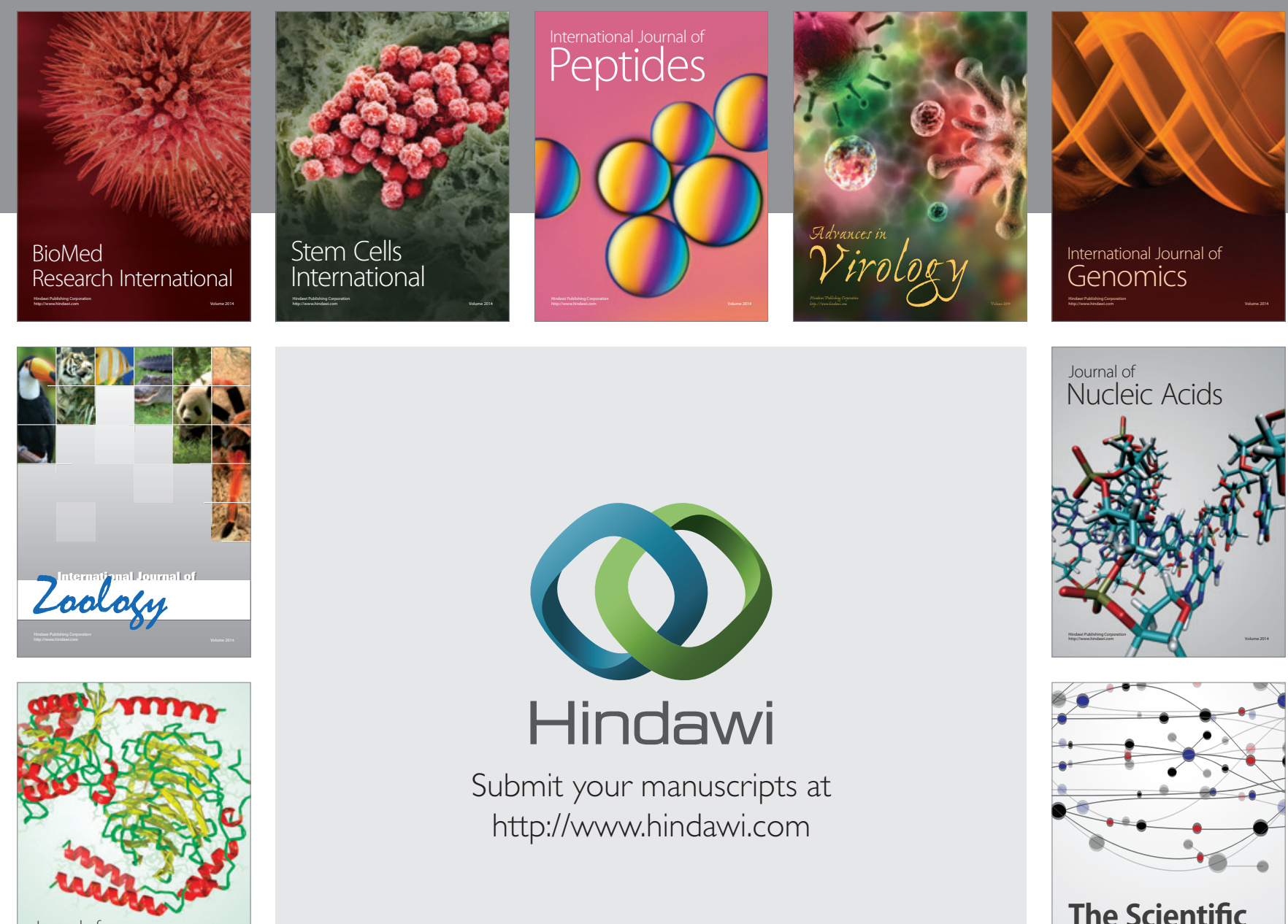

Submit your manuscripts at

http://www.hindawi.com

Journal of
Signal Transduction
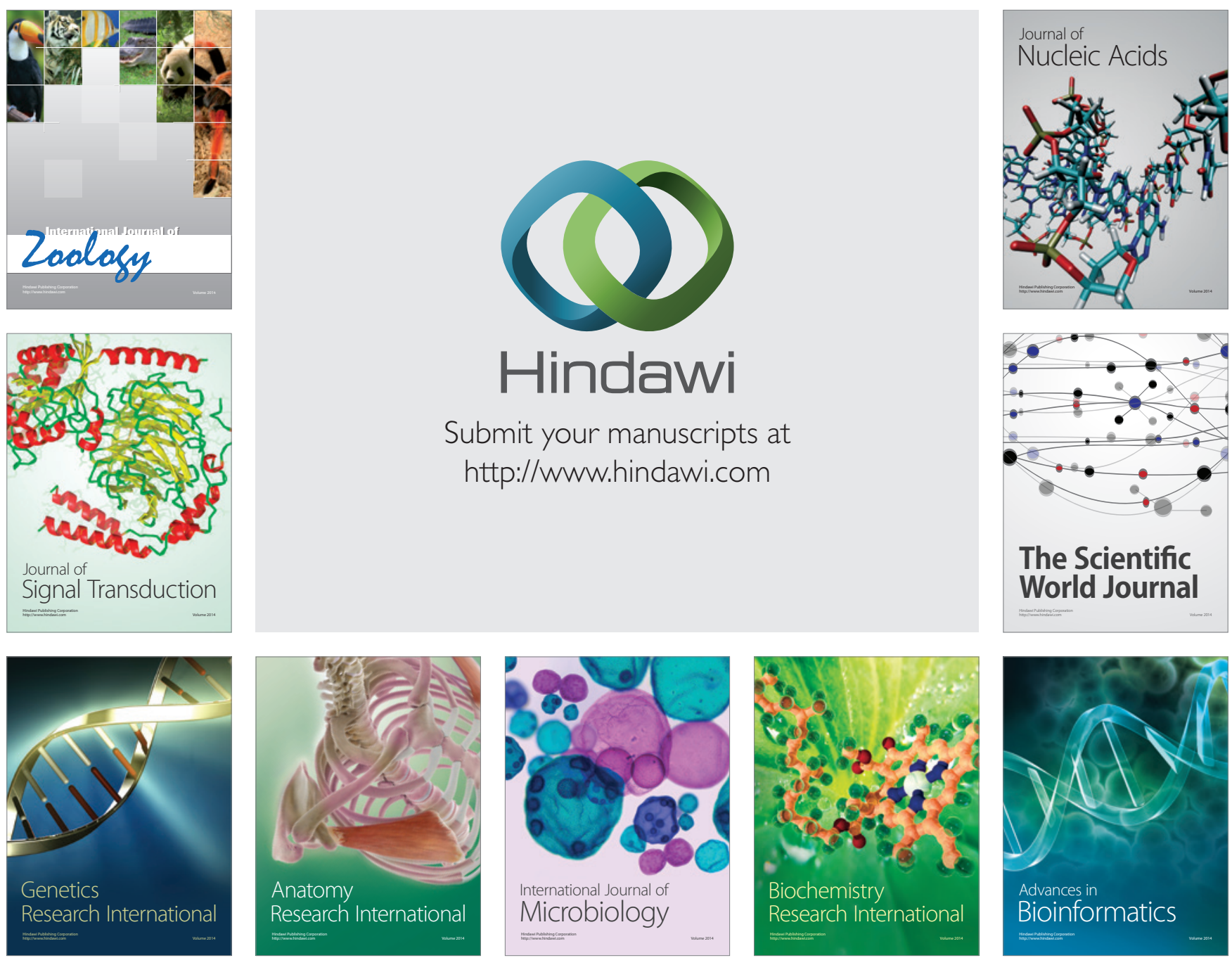

The Scientific World Journal
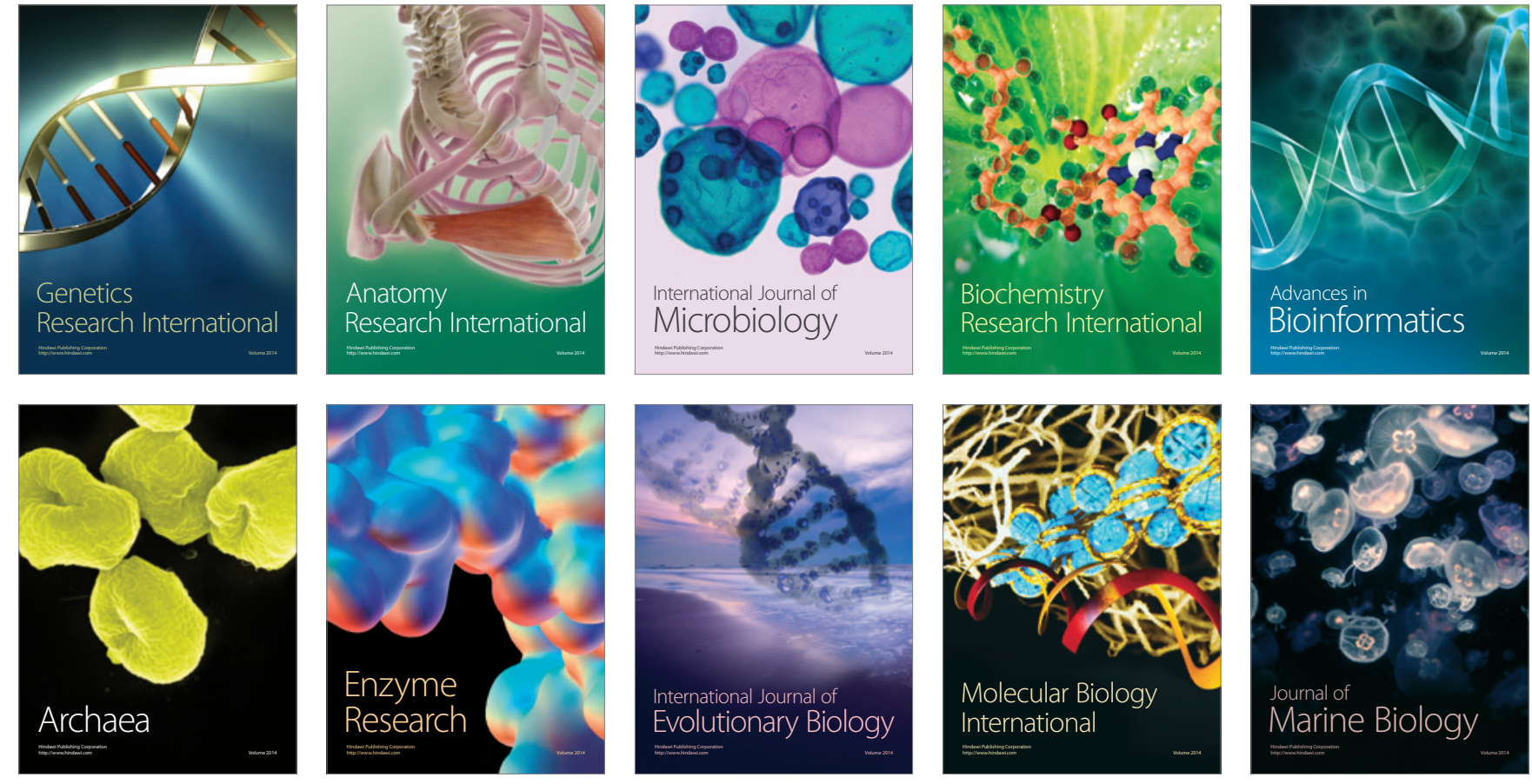